\title{
Skin ulcer disease of flounder Platichthys flesus in the northern Baltic Sea
}

\author{
Tom Wiklund, Göran Bylund
}

Institute of Parasitology, Åbo Akademi University, BioCity, Artillerig. 6, SF-20520 Åbo, Finland

\begin{abstract}
Skin ulcer disease of flounder Platichthys flesus (L.) was investigated at 7 sampling sites in the northern Baltic Sea, SW Finland, during 1987-1989. Disease prevalences ranged from 1.8 to $11.1 \%$ in different areas. A significant correlation was established between sex, fish length and disease prevalence. Males were more affected $(10.7 \%)$ than females $(3.1 \%)$ and larger fish showed higher disease prevalences than smaller ones. The length of the ulcerated flounders varied between 19 and $42 \mathrm{~cm}$. The ulcers were not randomly distributed on the fish trunk. They occurred mainly on the blind side of the males and on the eye side of the females. Ulcers on males tended to occur close to the lateral line; on females, the ulcers were scattered over the whole trunk. Bacterial examination of diseased specimens resulted in the isolation of a cytochrome oxidase-negative, atypical Aeromonas salmonicida, primarily from the ulcers.
\end{abstract}

KEY WORDS: Aeromonas salmonicida $\cdot$ Baltic Sea $\cdot$ Flounder $\cdot$ Ulcer disease

\section{INTRODUCTION}

Skin ulcers are frequently recorded from a large variety of fish species. In farmed fish, skin ulcerations are usually related to septicemic conditions caused by bacteria of the genera Vibrio, Aeromonas, Pseudomonas, etc. Ulcerative skin lesions in wild fish cannot, however, in some cases be traced back to septicemic infections (Burke \& Rodgers 1981, Austin \& Austin 1987. Wiklund 1990).

Different authors have attributed the development of skin ulcers in fish to different etiological factors such as injuries caused by fishing gear (LeTendre et al. 1972, Möller 1981, Mellergaard 1986, Dethlefsen et al. 1987. Mellergaard \& Nielsen 1990), pollution (Perkins et al. 1972, Larsen et al. 1978, Vethaak 1987), large salinity fluctuations (Rodgers \& Burke 1981, Möller 1984, 1990 , Vethaak 1992) or a low condition factor due to shortage of food (Möller 1981, 1990).

Flatfish seem to be more vulnerable to ulcerative skin lesions than most other fish groups. There are, for example, numerous reports of skin ulcer disease in several flatfish species from countries around the Baltic Sea, the North Sea, the British Isles and France
(Perkins et al. 1972, Grawinski 1976, Möller 1981, Nounou et al. 1981, Bucke et al. 1983, Wiklund \& Bylund 1985, Thulin et al. 1989, Vethaak 1992). Macroscopically the ulcers appear to develop in the same way in different flatfish species and in fish from different areas: starting from small hemorrhagic lesions, the epidermis sloughs off, exposing the underlying musculature but usually not penetrating deeply into it.

In most reports dealing with skin ulcer disease of flatfish, the primary etiology remains obscure. Most bacteria isolated from ulcerated fish are normal bacterial constituents of marine and brackish waters and seem to be secondary invaders rather than primary fish pathogens. Although ulcer disease in some cases seems to be more characteristic in fish resident in degraded water habitats, it has been difficult to relate the disease to specific chemicals or pollutants.

This report deals with the occurrence of skin ulcer disease in flounder Platichthys flesus (L.) on the Finnish coast, particularly in relation to size and sex of the affected fish, and to the spatial and seasonal variation in prevalences found. Subsequent papers will deal with our observations on etiological agents of the disease in this area. 


\section{MATERIALS AND METHODS}

Sampling area. The sampling sites (A to $G$ ) were located on the south and west coast of Finland (see Fig. 4). The salinity of the investigated area varies between 4 and $6 \%$ and the temperature of the surface water varies from freezing point in winter up to $20^{\circ} \mathrm{C}$ in summer. Most parts of the sampling area are normally covered with ice between December and April.

The northern Baltic Sea is generally considered polluted, but an immediate effect from pollution occurs only within Site B. This area is affected by effluents from several industries and agriculture and by sewage from the city of Björneborg (Oravainen 1989), inducing a very complex state of pollution. Site $B$ also receives fieshi watel flun the Kunn River. However, salinity close to the bottom at this sampling site is rather stable

Fishing operations and fish examination. The flounders were caught close to the shore, at depths between 2 and $30 \mathrm{~m}$. The samples were collected from commercial catches during 1987-1989. As the number of fish examined from 2 of the sampling sites ( $\&$ G) was small, these were excluded from some of the calculations. From Site F, samples were taken every month during the ice-free seasons. Most fish samples were caught with standing gill nets (mesh size 35 to $65 \mathrm{~mm}$ ). At each sampling, either all of the fish or a random subsample was examined. The fish were transported to the laboratory for examination.

Most of the flounders were sexed and the total length of all flounders was measured. The skin, fins and gills were examined for external lesions and most specimens were opened and examined for lesions in the visceral organs.

Virological and bacteriological sampling and processing. Virological examination of ulcer tissues from diseased fish was performed according to routine methods. The tissues tested were inoculated on 3 cell lines (FHM, RTG-2 and BF-2) and incubated at $15^{\circ} \mathrm{C}$ in 2 passages. The cell cultures were examined for cytopathic effects every day for 2 wk.

Bacteriological sampling was performed as described previously (Wiklund \& Bylund 1991). The results of the bacteriological examinations will be only briefly discussed in this paper.

Analysis of data. The prevalences of ulcer disease were calculated only on fish larger than $20 \mathrm{~cm}$, in accordance with recommendations of an ICES working group (Working Group on Pathology and Diseases of Marine Organisms; Anon. 1991).

All data were processed with computer programs (Supercalc, Statistix and Macintosh statistical programs) in order to establish correlations of disease prevaiences with fish length, sex and sampling station.

Because there was a significant correlation between disease prevalences and fish length and sex, respectively, the size and sex distribution of the fish sampled at a site had an immediate influence on the ulcer prevalence recorded for that site. An objective comparison of disease prevalences at different sites could not, therefore, be based only on the disease prevalences recorded. To permit comparisons, a theoretical disease prevalence for each site was calculated on the basis of the mean length of the fish, the sex ratio, and the regression lines for fish length and disease prevalence. The theoretical values were calculated according to the following method:

Disease prevalences were calculated separately for males and females from each site.

- The equations for the regression lines of the disease prevalences and fish length for the total number of males and females were calculated separately (Sites B to F).

- These equations, and the mean lengths of the males and the females at the different sites, were used to calculate theoretical disease prevalences.

- Using the theoretical disease prevalence and the

Table 1. Platichthys flesus. Total number of flounders examined at different sampling sites: year of sampling, sex distribution and mean lengths

\begin{tabular}{|c|c|c|c|c|c|c|c|c|}
\hline Site & $\begin{array}{l}\text { Catch } \\
\text { year }\end{array}$ & $\begin{array}{l}\text { Total no. of } \\
\text { examined } \\
\text { flounders }\end{array}$ & $\begin{array}{l}\text { Mean } \\
\text { length } \\
(\mathrm{cm})\end{array}$ & $\begin{array}{l}\text { No. of } \\
\text { sexed } \\
\text { flounders }\end{array}$ & \multicolumn{2}{|c|}{$\begin{array}{l}\text { Males } \\
n(\%) \text { Mean length } \\
\qquad(\mathrm{cm})\end{array}$} & \multicolumn{2}{|c|}{$\begin{array}{c}\text { Females } \\
n(\%) \text { Mean length } \\
\qquad(\mathrm{cm})\end{array}$} \\
\hline $\mathrm{A}$ & 1.988 & 216 & 24.0 & - & - & - & - & - \\
\hline B & $1987-1989$ & 778 & 25.7 & 720 & $203(28)$ & 23.9 & $517(72)$ & 26.5 \\
\hline $\mathrm{C}$ & $1987-1989$ & 1.176 & 22.8 & 1045 & $418(40)$ & 21.1 & $627(60)$ & 24.3 \\
\hline$D$ & $1987-1989$ & 1490 & 25.7 & 1249 & $593(47)$ & 25.2 & $656(53)$ & 25.2 \\
\hline$E$ & $1987-1988$ & 623 & 30.4 & 621 & $167(27)$ & 29.3 & $454(73)$ & 30.9 \\
\hline $\mathrm{F}$ & $1987-1989$ & 3274 & 28.9 & 3009 & $1169(39)$ & 28.0 & $1840(61)$ & 29.3 \\
\hline G & 1988 & 56 & 26.7 & - & - & - & - & - \\
\hline$A-G$ & $1987-1989$ & 7613 & 27.0 & 6644 & $2550(38)$ & 26.0 & $4094\{62\}$ & 27.7 \\
\hline
\end{tabular}




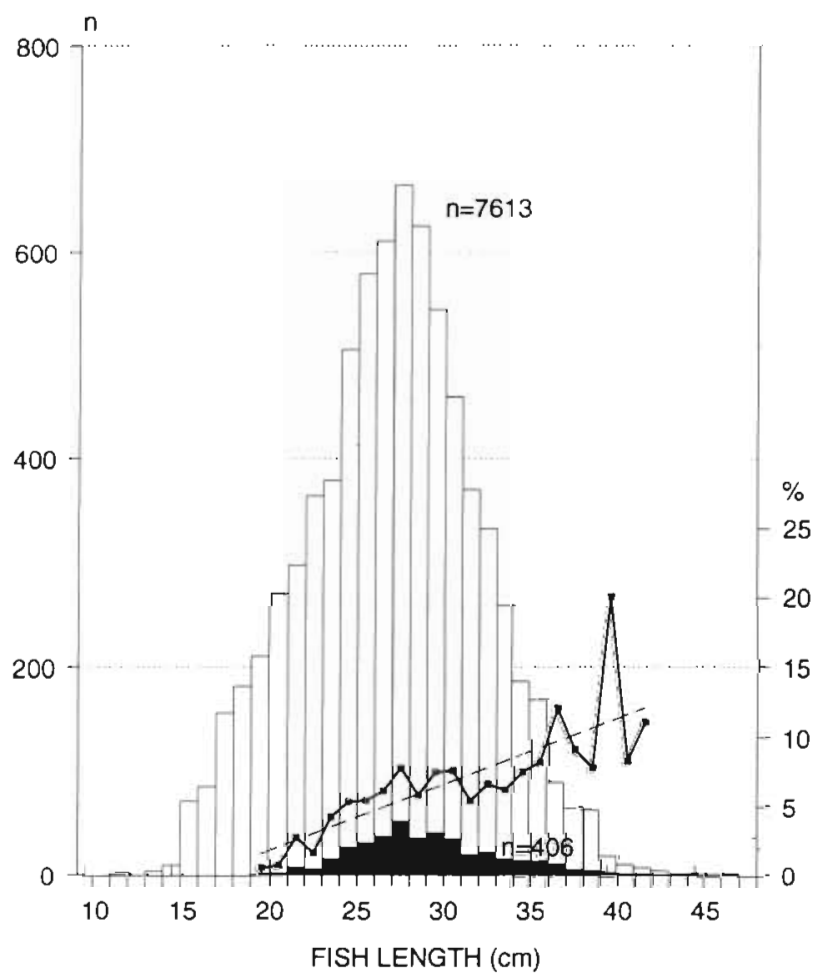

Fig. 1. Platichthys flesus. Length distribution of all examined (white bars) and ulcerated (black bars) flounders. (-) Percentage distribution of ulcerated flounders of the appropriate length class. (- -) Regression line for the percentage distribution of diseased fish within the appropriate length class

number of examined fish, the theoretical number of diseased males and females, respectively, was calculated for each site.

- The overall theoretical disease prevalence for all sites was based on the theoretical number of diseased fish of both sexes in relation to the total number of fish examined.

The theoretically derived number of diseased fish was compared with the observed number of diseased fish using a $\chi^{2}$ test.

\section{RESULTS}

\section{Description of fish samples}

A total of 7613 flounders were examined. The fish examined varied in length from 11 to $47 \mathrm{~cm}$ (Fig. 1) with an average length of 27.0 $\mathrm{cm}$. There were marked differences in the mean length among the sampling sites, ranging from 22.8 to $30.4 \mathrm{~cm}$ (Table 1).

Of the flounders examined for sex, only a few were completely infertile; these were ex- cluded from the analyses. Most $(62 \%)$ of the fish were females, but clear differences in sex ratio were observed among the different sampling sites (Table 1). Females, however, dominated at every site. The females were on average larger than the males at every site, except Site D.

\section{Disease prevalences}

Relationship between fish length and ulceration rates

Of the flounders examined, 723 specimens $(9 \%)$ were shorter than $20 \mathrm{~cm}$ and were thus excluded from the calculation of disease prevalences.

A total of 6890 flounders were included in the analysis. Of the fish examined, 405 specimens (5.9\%) showed epidermal ulcerations (Table 2). Only 1 ulcerated fish shorter than $20 \mathrm{~cm}$ was observed. A positive correlation was found between the prevalences of ulcerated fish and fish length. The relationship was described by the following linear regression: disease prevalence $=-7.835+0.482 \times$ fish length $r=0.80$; $\mathrm{p}<0.001$ (Fig. 1).

Influence of sex on the disease prevalences

Out of 6031 fish examined from Sites B, C, D, E \& F, $10.7 \%$ of the males and $3.1 \%$ of the females showed skin ulcerations (Table 3). The difference in disease prevalence between males and females was statistically significant $\left(\chi^{2}\right.$ test, $\left.p<0.001\right)$. The mean length of the males and females was 27.1 and $28.5 \mathrm{~cm}$ respectively. The differences in mean length did not, however, explain the different disease prevalences because there were clear differences between the disease prevalences even when considering males and females in the same length class (Fig. 2)

Table 2. Platichthys flesus. Disease prevalences and mean lengths of flounders $(>20 \mathrm{~cm})$ at different sites

\begin{tabular}{|cccccc|}
\hline Site & $\begin{array}{c}\text { No. of fish } \\
>20 \mathrm{~cm}\end{array}$ & $\begin{array}{c}\text { Mean length } \\
\text { of fish }>20 \mathrm{~cm} \\
(\mathrm{~cm})\end{array}$ & $\begin{array}{c}\text { No. of } \\
\text { diseased } \\
\text { fish }>20 \mathrm{~cm}\end{array}$ & $\begin{array}{c}\text { Disease } \\
\text { preval. } \\
(\%)\end{array}$ & $\begin{array}{c}\text { Mean length } \\
\text { of diseased } \\
\text { fish }(\mathrm{cm})\end{array}$ \\
\hline A & 173 & 25.3 & 8 & 4.6 & 26.6 \\
B & 686 & 26.7 & 76 & 11.1 & 28.7 \\
C & 826 & 25.2 & 38 & 4.6 & 26.0 \\
D & 1308 & 26.8 & 69 & 5.3 & 28.1 \\
E & 623 & 30.4 & 38 & 6.1 & 29.6 \\
F & 3219 & 29.1 & 175 & 5.4 & 30.5 \\
G & 55 & 26.8 & 1 & 1.8 & 27.0 \\
Total & 6890 & 27.9 & 405 & 5.9 & 29.1 \\
\hline
\end{tabular}


Table 3. Platichthys flesus. Observed and theoretically calculated disease prevalences for females and males, and total number of sexed flounders at sampling sites B to F

\begin{tabular}{|c|c|c|c|c|c|c|}
\hline Site & $\begin{array}{l}\text { Total no. of } \\
\text { examined } \\
\text { fish }\end{array}$ & $\begin{array}{l}\text { Mean } \\
\text { length }\end{array}$ & $\begin{array}{c}\text { Observed } \\
\text { prevalences } \\
\text { of ulcers }\end{array}$ & $\begin{array}{l}\text { Calculated } \\
\text { prevalences } \\
\text { of ulcers }\end{array}$ & $\begin{array}{l}\text { Observed no. } \\
\text { of ulcerated } \\
\text { fish }\end{array}$ & $\begin{array}{c}\text { Theoretical no } \\
\text { of ulcerated } \\
\text { fish }\end{array}$ \\
\hline \multicolumn{7}{|c|}{ Females } \\
\hline B & 470 & 27.4 & 6.8 & 1.7 & 32 & 8.0 \\
\hline C & 501 & 25.9 & 1.2 & 1.3 & 6 & 6.5 \\
\hline $\mathrm{D}$ & 545 & 26.7 & 2.2 & 1.5 & 12 & 8.2 \\
\hline$E$ & 454 & 30.9 & 3.1 & 3.1 & 14 & 14.1 \\
\hline F & 1813 & 29.5 & 3.0 & 2.4 & 55 & 43.5 \\
\hline Total & 3783 & 28.5 & 3.1 & 2.0 & 119 & 75.7 \\
\hline \multicolumn{7}{|l|}{ Males } \\
\hline $\mathrm{B}$ & 166 & 25.3 & 22.9 & 12.5 & 38 & 20.8 \\
\hline $\mathrm{C}$ & 255 & 23.2 & 122 & 95 & 31 & 24.2 \\
\hline$D$ & 5.17 & 26.3 & 9.1 & 12.8 & 47 & 66.2 \\
\hline$E$ & 167 & 29.3 & 14.4 & 11.3 & 24 & 18.9 \\
\hline F & 1143 & 28.2 & 8.8 & 12.1 & 101 & 138.3 \\
\hline Total & 2248 & 27.1 & 10.7 & 12.6 & 241 & 283.3 \\
\hline \multicolumn{7}{|l|}{ Total } \\
\hline B & 636 & & 11.0 & 4.5 & 70 & 28.8 \\
\hline C & 756 & & 4.9 & 4.1 & 37 & 30.7 \\
\hline $\mathrm{D}$ & 1062 & & 5.6 & 7.0 & 59 & 74.4 \\
\hline$E$ & 621 & & 6.1 & 5.3 & 38 & 33.0 \\
\hline F & 2956 & & 5.3 & 6.2 & 156 & 181.8 \\
\hline Totall & 6031 & & 6.0 & 6.0 & 360 & 359.0 \\
\hline
\end{tabular}

The disease prevalence for males increased rapidly with increasing fish length following a third-degree regression line $\left(y=-702.23835+75.09765 x-2.60968 x^{2}\right.$ $+0.02996 x^{3} ; r=0.72$ ). The disease prevalence for females increased more slowly, following an exponential regression $\left(y=0.012423 \mathrm{e}^{017844 x} ; \mathrm{r}=0.924\right)$ (Fig. 2).

Among the different sampling sites, the disease prevalences varied from 8.8 to $22.9 \%$ for males and from 1.2 to $6.8 \%$ for females (Table 3 ). The difference in disease prevalence between males and females was statistically significant for all sites $\left(\chi^{2}\right.$ test, $\mathrm{p}<0.001$ )

\section{Spatial differences in disease prevalences}

The disease prevalences of fish from the different sites varied between 1.8 and $11.1 \%$ (Table 2). The prevalences at Sites A, C, D, E \& F were rather similar $(4.7$ to $6.1 \%)$ but the prevalence at Site $B$ was higher $(11.1 \%)$. Because the disease prevalence increased with increasing fish length and because the mean length was different at all the sites investigated, a direct comparison of the mean prevalences of the different sites (Table 2) was not relevant. When considering the size and sex distribution of the fish, the elevated disease prevalence at Site B was, however, even more evident (Table 3).

The calculated theoretical disease prevalences (Table 3) within the different sites differed significantly ( $\chi^{2}$ test, $\left.\mathrm{p}<0.001\right)$ from the observed values at Site $B$ and insignificantly at the other sites.

\section{Seasonal variation in prevalences}

The most conclusive results concerning seasonal prevalences were obtained from Site F, which was sampled monthly. Fig. 3 shows that the disease prevalence varied considerably over the course of a year. During the study (1987-1989) it varied between 2 and $18 \%$ at Site $F$. The lowest disease prevalences were observed in spring; increased prevalences occurred in late summer every year. At the other sampling sites, the disease prevalences were also higher in the autumn than in the spring (Fig. 4).

\section{Intensity of ulceration}

The diseased males had, on average, 1.7 ulcers fish $^{-1}$ and the diseased females 1.5 ulcers fish ${ }^{-1}$. At all 

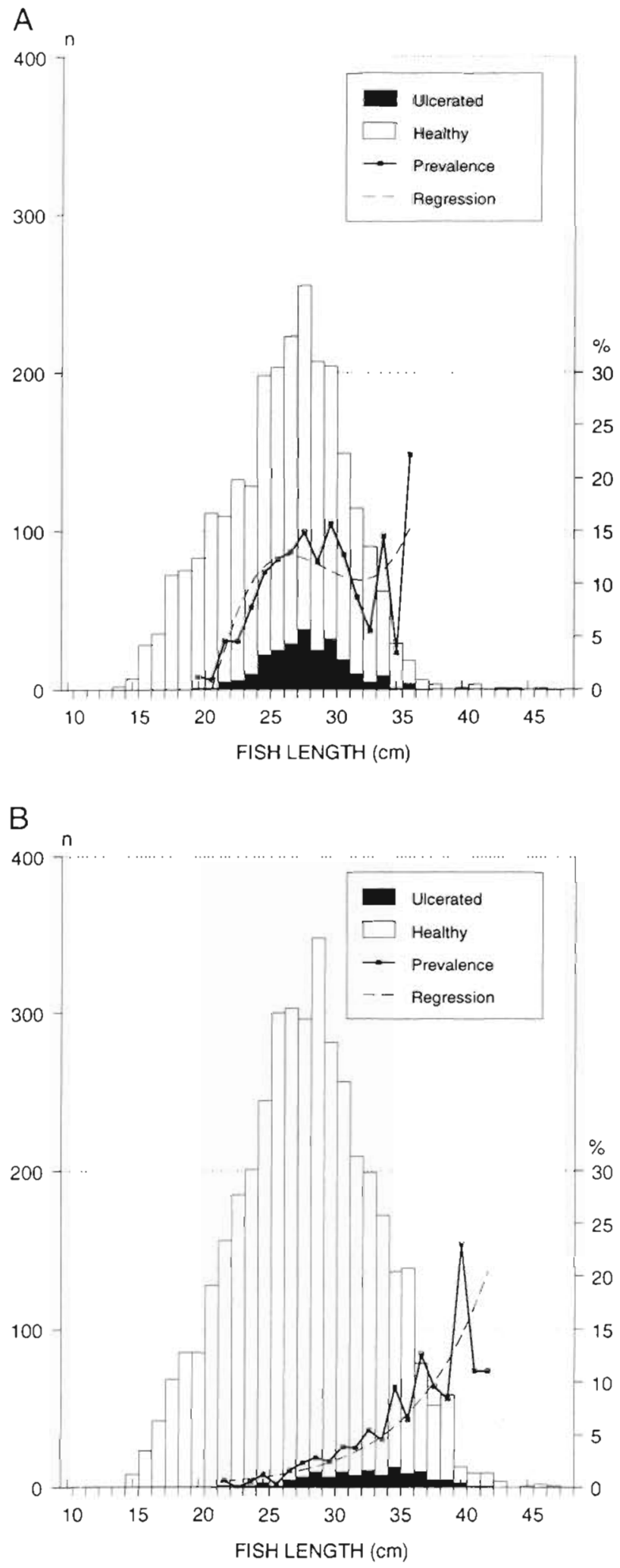

Fig. 2. Platichthys flesus. Length distribution of all examined (white bars) and ulcerated (black bars) (A) male and (B) female flounders. (-) Percentage distribution of ulcerated flounders in the appropriate length class. (- -) Regression line for the percentage distribution of diseased fish within the appropriate length class sites, the number of ulcers per male was equal to or higher than that in females. The highest intensity of ulceration was recorded at Site B (2.3 for males and 1.7 for females).

\section{Location of ulcers}

Ulcers on males were predominantly located near the lateral line; ulcers on females were more scattered over the trunk (Fig. 5).

Of the diseased males ( $\mathrm{n}=242$ ), $85 \%$ showed ulcers on the blind side, $12 \%$ on the eye side and $4 \%$ had ulcers on both sides. The location of the ulcers on the trunk of the females $(n=119)$ was almost the opposite. Of the diseased females, $66 \%$ showed ulcers on the eye side, $32 \%$ had ulcers on the blind side and $3 \%$ showed ulcers on both sides (Table 4). The difference in the location of ulcers between males and females was statistically significant $\left(\chi^{2}\right.$ test, $\left.\mathrm{p}<0.001\right)$.

\section{Description of ulcers}

The ulcers were mostly open, dark reddish wounds; they were often rounded, but irregular forms were also encountered. Ulcers on the head often penetrated the soft tissue down to the bones. Ulcers on the trunk were mostly superficial and did not penetrate deeply into the muscle tissue. The size of the ulcers varied from small lesions 1 to $2 \mathrm{~mm}$ in diameter to large eroded areas 1 to $2 \mathrm{~cm}$ in diameter

Ulcer development could be divided into 3 stages: initially, weak hemorrhages occurred in the skin. These then developed into a white lesion surrounded by a rim of hemorrhagic inflammatory tissue. In the final, true ulcer stage, the skin tissue was eroded away and the muscle tissue was exposed. Ulcers were typically surrounded by a white rim of necrotic tissue around which there was a zone of red hemorrhages in the skin. Apparently, healing of the ulcers occurred frequently, as scar formation was often seen on the blind side. Scar formation on the eye side was not, however, easily detected as it was often concealed by the dark pigmentation of the skin.

Table 4. Platichthys flesus. Location of ulcers on the blind side, the eye side, and both sides of diseased male and female flounders

\begin{tabular}{|c|c|c|c|c|c|c|}
\hline \multirow[t]{2}{*}{ Sex } & \multicolumn{2}{|c|}{$\begin{array}{l}\text { Ulcers only } \\
\text { on blind side }\end{array}$} & \multicolumn{2}{|c|}{$\begin{array}{l}\text { Ulcers only } \\
\text { on eye side }\end{array}$} & \multicolumn{2}{|c|}{$\begin{array}{l}\text { Ulcers } \\
\text { on both sides }\end{array}$} \\
\hline & $\mathrm{n}$ & $\%$ & $n$ & $\%$ & $\mathrm{n}$ & $\%$ \\
\hline Males & 205 & 84.7 & 28 & 11.6 & 9 & 3.7 \\
\hline Females & 38 & 31.9 & 78 & 65.5 & 3 & 2.5 \\
\hline Total & 243 & 67.3 & 106 & 29.4 & 12 & 3.3 \\
\hline
\end{tabular}




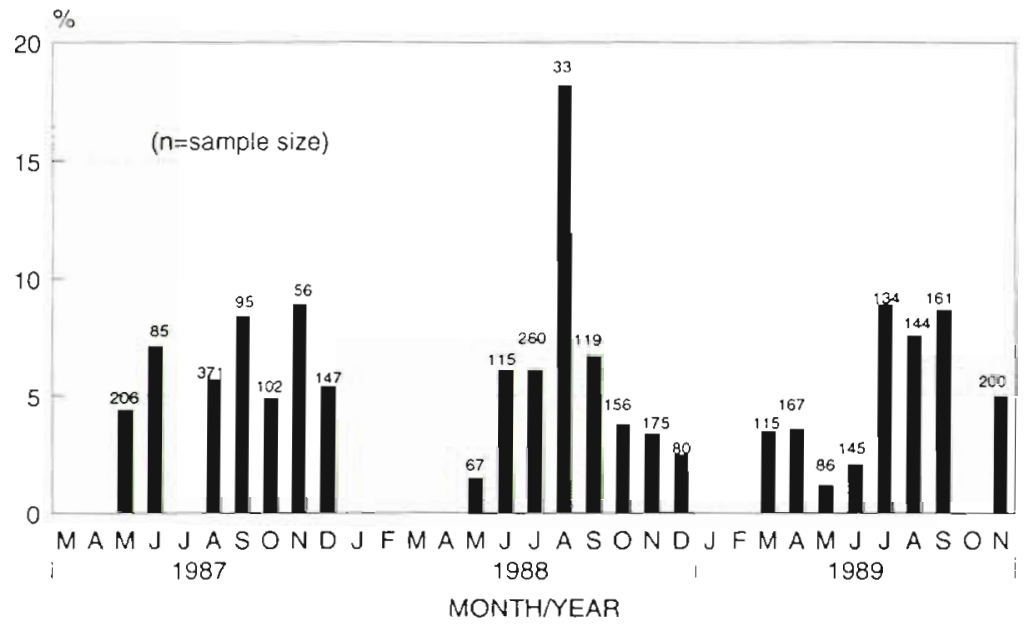

Fig. 3. Platichthys flesus. Monthly ulcer disease prevalences (vertical axis) at Site F. Numbers above bars indicate number of flounders examined

\section{Virological and bacteriological results}

Virological examination of ulcer tissues from 40 fish on 3 different cell cultures did not reveal any virus infection.

Bacteriological examination of ulcers resulted in the isolation of a slow-growing bacterium, identified as an atypical, cytochrome oxidase-negative Aeromonas salmonicida (Wiklund \& Bylund 1991). This bacterium was isolated from $54 \%$ of the ulcers examined (162 fish specimens). Only from $3(1.9 \%)$ of these specimens was the bacterium also isolated from the viscerāl orgañon. Chaldcieristics of the isolates are given by Wiklund \& Bylund (1991).
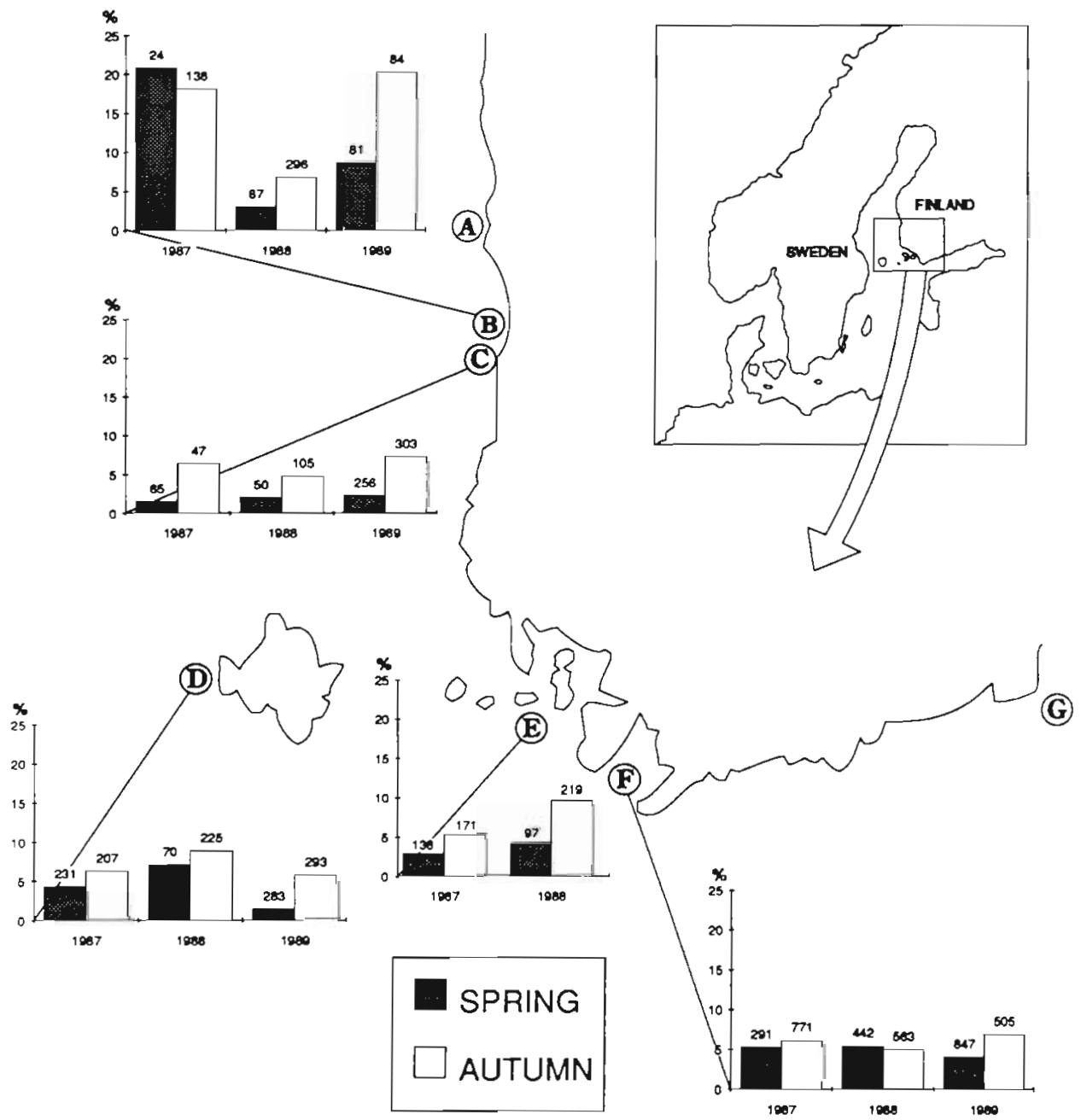

Fig. 4. Platichthys flesus. Locatum of sampling sites in the Baltic Sea, and ulcer disease prevalences in flounder at different sites (B to F), and in different years (1987-1989) and seasons. Values above bars indicate number of flounders examined (Sites $A$ \& $G$ not included due to small number of fish examined) 


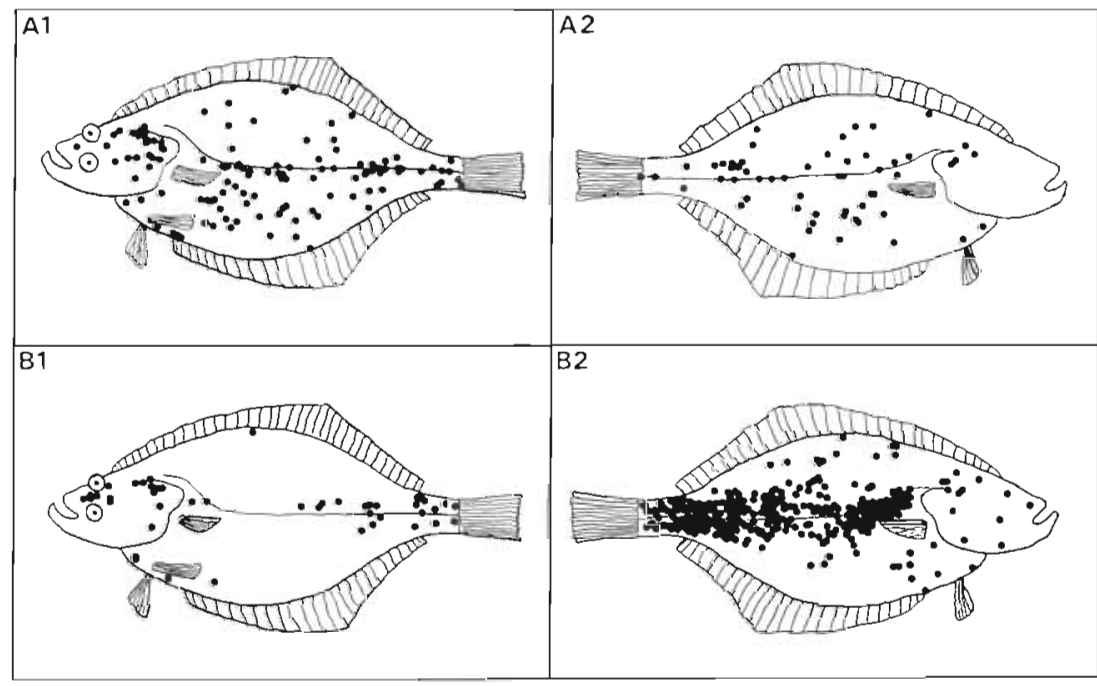

Fig. 5. Platichthys flesus. Distribution of ulcers (black spots) on the eye side $(A 1, n$ $=116$ and $B 1, n=45)$ and the blind side $(A 2, n=57$ and $B 2, n=357)$ of the trunk of (A1 \& A2) female and (B1 \& B2) male flounders

\section{DISCUSSION}

One of the first reports of skin ulcer disease in flounder was published by Johnstone (1905). The author assumed that the ulcer was caused by a lamprey. It was not until the 1970 s and 1980 s that more systematic studies were performed on the ulcer disease of flounder. The occurrence of ulcers on flounders, as well as on other flatfish species, has been reported from different areas. Previous reports of ulcerations in flounder are summarized in Table 5. With few exceptions, the prevalences of ulcer disease in most of the earlier investigations varied between 0 and $4 \%$ (see Table 5). Compared to these values the prevalences in the present investigation must be considered high. Our results, however, showed a significant correlation between fish length and ulcer prevalence. A comparison of the prevalences among samples with different length distributions may thus be misleading. Most authors in older papers have calculated disease prevalences of the samples, giving no information of the disease rates in different length classes of the fish. In fact, some authors did not make any mention of the length distribution of the fish examined (see Table 5).

Taking into account the method of calculating prevalences (only fish larger than $20 \mathrm{~cm}$ ) our results can be compared to those of Vethaak (1987) and Möller (1990). The disease prevalences in the present investigation are, however, higher than those reported by Vethaak (1987) (0.9 to $4.4 \%$ ) and Möller (1990) (2.9\% in 1981-1982 and $4.9 \%$ in 1984-1986 in regions of the River Elbe; calculated from values given by the au- thor). Vethaak (1992) reported adjusted prevalences (referring to a disease probability based on logit analysis) up to $35 \%$ for female flounder 20 to $24 \mathrm{~cm}$ in length, in one region of the Wadden Sea. Also, in the present investigation very high prevalences ( 25 to $64 \%$ ) were observed for male flounders 25 to $30 \mathrm{~cm}$ in length during each autumn at one site (B); however, the number of fish examined was rather low, making the results less significant. The observed disease prevalences at this site were significantly higher than expected (theoretically calculated values). This indicates that the flounder in this area were affected by an unknown factor or factors not present in the other areas, thus making the fish more susceptible to the disease. Site B was of a more estuarine type than the other sites investigated; also the pollution load in this area was higher than in the other areas. The nutritional status of the flounder was also lower at this site than at the other sites sampled, thus perhaps imposing a nutritional stress on the fish (unpubl. results).

Although we examined approximately 700 flounders that were shorter than $20 \mathrm{~cm}$, only 1 specimen was affected by ulcer disease. In other investigations, however, smaller fish with ulcer disease were frequently encountered (e.g. Möller 1981, 1984, 1990, Vethaak 1992). In the northern Baltic Sea, the length of the smallest flounders recorded with skin ulcers (19 to $20 \mathrm{~cm}$ ) correlates with the length of the fish at sexual maturation (Suuronen 1979). Although the occurrence of ulcer disease in flounder correlates with the sexual maturation of the fish, there is no definite proof as to the nature of the factor related to the maturation process that induces the ulcers or makes the fish susceptible to the disease. Sexual maturation induces a number of behavioral and anatomical changes in the fish (e.g. feeding migration, spawning migration, individual spawning behavior, structural changes in the skin) that might account for susceptibility to ulcers.

In several previous investigations, higher prevalences of the ulcer disease in flounder were reported from autumn than from spring samples (Christensen et al. 1981, Möller 1981, 1984, Vethaak 1985, 1992). Our results confirm these observations. The monthly sampling at Site F showed that the prevalences within an area can vary considerably during the year. This should be given enough consideration when evaluat- 
Table 5. Platichthys flesus. Observed prevalences of ulcer disease of flounder in different northeast Atlantic areas including results from this study. n.m. not mentioned

\begin{tabular}{|c|c|c|c|c|}
\hline Site & $\mathrm{n}$ & $\begin{array}{l}\text { Ulcers } \\
\%\end{array}$ & $\begin{array}{l}\text { Fish } \\
\text { size }\end{array}$ & Source \\
\hline Irish Sea & 35 & 0 & $>15 \mathrm{~cm}$ & Perkins et al. (1972) \\
\hline $\begin{array}{l}\text { Irish Sea } \\
\text { SE England }\end{array}$ & $\begin{array}{l}397 \\
124\end{array}$ & $\begin{array}{l}1.3 \\
0.8\end{array}$ & $\begin{array}{l}13-40 \mathrm{~cm} \\
19-38 \mathrm{~cm}\end{array}$ & $\begin{array}{l}\text { Shelton \& Wilson (1973) } \\
\text { Shelton \& Wilson (1973) }\end{array}$ \\
\hline Polish coast & $2500^{\alpha}$ & $3.8-16.8$ & n.m. & Grawinski (1976) \\
\hline German Bight & 554 & $1.4-5.4$ & n.m. & Dethlefsen (1980) \\
\hline Weser estuary, Germany & n.m. & 1.6 & $>10 \mathrm{~cm}$ & Moller (1981) \\
\hline Elbe estuary, Germany & n.m. & 0.9 & $>10 \mathrm{~cm}$ & Möller (1981) \\
\hline German Bight & n.m. & 0.9 & $>10 \mathrm{~cm}$ & Moller (1981) \\
\hline Lilla Bält, Denmark & 2686 & 2.1 & n.m. & Christensen et al. (1981) \\
\hline SW Raltic SeA & 272 & 1.5 & n.m. & Dethlefsen \& Watemañ $(1982)$ \\
\hline SW Baltic Sea & 315 & 4.1 & $\mathrm{n} \cdot \mathrm{m}$ & Dethlefsen \& Watermann (1982) \\
\hline SW Baltic Sea & 3116 & 0.3 & n.m. & Dethlefsen \& Watermann (1982) \\
\hline Thames estuary & 129 & 3.1 & n.m. & Bucke et al. (1983) \\
\hline SE England & 454 & 1.1 & n.m. & Bucke et al. (1983) \\
\hline SE England & 23 & 0 & n.m. & Bucke et al. (1983) \\
\hline Elbe estuary, Germany & 14364 & 1.4 & $>12 \mathrm{~cm}$ & Möller (1984) \\
\hline Dutch coast & 1280 & 0.9 & $>20 \mathrm{~cm}$ & Vethaak (1987) \\
\hline Dutch coast & 909 & 1.1 & $>20 \mathrm{~cm}$ & Vethaak (1987) \\
\hline Dutch coast & 465 & 2.4 & $>20 \mathrm{~cm}$ & Vethaak (1987) \\
\hline Dutch coast & 1576 & 4.4 & $>20 \mathrm{~cm}$ & Vethaak (1987) \\
\hline Dutch coast & 1884 & 3.9 & $>20 \mathrm{~cm}$ & Vethaak (1987) \\
\hline Swedish coast & 219 & 0 & $\mathrm{n} \cdot \mathrm{m}$ & Thulin et al. (1989) \\
\hline Swedish coast & 68 & 1.5 & $\mathrm{n} \cdot \mathrm{m}$. & Thulin et al. (1989) \\
\hline Swedish coast & 272 & 2.6 & n.m. & Thulin et al. (1989\} \\
\hline $\begin{array}{l}\text { River Elbe, Region II + III, } \\
\quad 1981-1982\end{array}$ & 1934 & $2.9^{\mathrm{b}}$ & $20-44 \mathrm{~cm}$ & Möller (1990) \\
\hline $\begin{array}{l}\text { River Elbe, Region II + III, } \\
\quad 1984-1986\end{array}$ & 2864 & $4.9^{\mathrm{D}}$ & $20-44 \mathrm{~cm}$ & Möller (1990) \\
\hline Wadden Sea & 1164 & $0.6^{\mathrm{b}}$ & $<15 \mathrm{~cm}$ & Vethaak (1992) \\
\hline Wadden Sea & 8260 & $8.9^{b}$ & $>15 \mathrm{~cm}$ & Vethaak (1992) \\
\hline SW Finnish coast, Site B & 686 & 11.1 & $>20 \mathrm{~cm}$ & This study \\
\hline SW Finnish coast, Site C & 826 & 4.6 & $>20 \mathrm{~cm}$ & This study \\
\hline SW Finnish coast, Site D & 1308 & 5.3 & $>20 \mathrm{~cm}$ & This study \\
\hline SW Finnish coast, Site E & 623 & 6.1 & $>20 \mathrm{~cm}$ & This study \\
\hline SW Finnish coast, Site F & 3219 & 5.4 & $>20 \mathrm{~cm}$ & This study \\
\hline
\end{tabular}

ing changes in disease prevalences from year to year and when comparing disease prevalences in different areas sampled at different seasons.

The fact that there was a significant difference in the disease prevalence between males and females was unexpected. It remains to be determined whether this difference was induced by differences in susceptibility to the disease, different behavioral or migrational patterns of the fish or by other factors. In contrast, Vethaak (1992) found no significant differences in ulcer disease prevalences between male and female flounders in Dutch coastal waters.
The different distribution pattern of the ulcers on the blind side of male and the eye side of female flounders is also surprising. This phenomenon has not been observed in other investigations. It was, however, previously reported that ulcers in dab, plaice and flounder occur mainly on the blind side of the fish (Nounou et al. 1981. Wiklund \& Bylund 1985, Vethaak 1992). The reason for the different distribution is unknown. Contributing factors could be different general behavior, especially different spawning behavior, or it could be due to different morphological or physiological features between the sexes. 
From descriptions of the ulcers on flatfish in other reports (Nounou et al. 1981, Bucke et al. 1983) it can be concluded that the ulcers examined in the present investigation were of the same type as those described from other regions.

In our bacteriological surveys, we were able to isolate a bacterium, presumptively described as a cytochrome oxidase-negative, atypical Aeromonas salmonicida (Wiklund \& Bylund 1991). To our knowledge, there have been no previous reports of the same type of atypical $A$. salmonicida from ulcerated flounders. Vethaak (1992) reported the isolation of $A$. salmonicida, but the author did not mention whether it was a typical or an atypical strain or whether it was isolated from a diseased or a healthy specimen.

The virological examinations in the present work gave negative results. A virological etiology cannot, however, be excluded although the development and appearance of the ulcers (i.e. open wounds with tissue erosion) did not suggest involvement of viruses as the main etiological agents.

The data presently available indicate that the skin ulcer disease of flounders in the northern Baltic Sea is a rather complex disease syndrome. Several factors like sex, fish size and sampling season seemed to influence the prevalences.

The high disease prevalences in the areas investigated are difficult to explain. The flounder is a fish of little commercial value in this region, although the fishing intensity for other fish species is high. Mechanical injuries in the fish due to 'catch and reject' with subsequent bacterial invasions may be one factor behind the high ulcer prevalence. Vethaak (1992) concluded that there was no correlation between prevalence of ulcer disease in different regions and the fishing activity off the Dutch coast. He recorded fishing activity as the number of eel fyke nets used in different areas, but the fishing intensity of this gear on flounder was not reported.

Möller (1990) and Vethaak (1992) concluded that high salinity fluctuations in certain areas of the North Sea coastal areas and river estuaries may contribute to high ulcer disease prevalences. The salinity in the areas in this study was low but rather stable. Only at Site B were there fluctuations; these occurred in spring due to freshwater outflow from the Kumo River. Daily salinity fluctuations as reported by Möller (1990) and Vethaak (1992) do not occur in the area sampled in this study.

The present results indicate that further investigations on the etiology of skin ulcer disease of flounder should focus more attention on the differences in the disease pattern between male and female fish, as well as between juvenile and adult individuals.
Acknowledgements. The authors gratefully acknowledge all fishermen who delivered fish for the investigation. The field assistance of 1. Böckerman, S. Eklöw, P. Heikkilä, B. Nyström, C. Oetken, C. Rabergh, V. Salonen and D. Toivola is greatly appreciated. We are also indebted to Christine Ekkommonen at the State Veterinary Institute in Helsingfors for the virological examınations. The research was financed by the Ministry of Agriculture and Forestry, and the Ministry of Environment.

\section{LITERATURE CITED}

Anon. (1991). Report of the working group on pathology and diseases of marine organisms. Ostend, 19-22 February, 1991. C.M. -ICES/F:42

Austin, B., Austin, D. A. (1987). Bacterial fish pathogens: disease in farmed and wild fish. Ellis Horwood Limited, Chichester

Bucke, D., Feist, S. W., Norton, M. G., Rolfe, M. S. (1983). A histopathological report of some epidermal anomalies of Dover sole. Solea solea L., and other flatfish species in coastal waters off south-east England. J. Fish Biol. 23: $565-578$

Burke, J., Rodgers, L. (1981). Identification of pathogenic bacteria associated with the occurrence of 'red spot' in sea mullet Mugil cephalus L., in south-eastern Queensland. J. Fish Dis. 4: 153-159

Christensen, N. O., Dalsgaard, 1., Larsen, J. L. (1981). Patobiologiske og mikrobiologiske undersögelser i Lillebält i 1979; Fiskesygdomme badevandskvalitet (Pathoblological and microbiological investigations in Lillebält in 1979. Fish diseases - water quality). Den Kgl. Veterinär- og Landbohojskole, Copenhagen

Dethlefsen, V. (1980). Observations on fish diseases in the German Bight and their possible relation to pollution. Rapp. P.-v. Reun. Cons. int. Explor. Mer 179: 110-117

Dethlefsen, V., Watermann, B. (1982). Diseases of major fish species in western Baltic Sea. C.M.-ICES/E:19: 1-20

Dethlefsen, V., Watermann, B., Hoppenheit. M. (1987). Diseases of North Sea dab (Limanda limanda L.) in relation to biological and chemical parameters. Arch. FischWiss. $37 \cdot 107-237$

Grawinski, E. (1976). Fish diseases of Gadidae and Pleuronectiadae families. Med. weter. 34: 404-407

Johnstone, J. (1905). Internal parasites and diseased conditions of fishes. Rep. Lancs. Sea-Fish Lab. 13: 98-120

Larsen, J L., Jensen, N. J., Christensen, N. O. (1978). Water pollution and the ulcer syndrome in the cod (Gadus morhua). Vet. Sci. Commun. 2: 207-216

LeTendre, G. C., Schneider, C. P., Ehlinger, N. F. (1972). Net damage and subsequent mortality from furunculosis in smallmouth bass. N. Y. Fish Game J. 19: 73--82

Mellergaard, S. (1986). Fishing gear induced ulcerations in cod. In: Dethlefsen, V., Egidius, E., McVicar, A. H. (eds.) Methodology of fish disease surveys. Report of a seagoing workshop held on R/V 'Anton Dohrn' 3-12 January 1984. Coop. Res. Rep. 140: 22-23

Mellergaard, S., Nielsen, E. (1990). Fish disease investigations in Danish coastal waters with special reference to the impact of oxygen deficiency. C.M.-ICES/E:6: 1-21

Möller, H. (1981). Fish diseases in German and Danish coastal waters in summer 1980. Meeresforsch. 9: 1-16

Möller, H. (1984). Dynamics of fish diseases in the lower Elbe river. Helgoländer Meeresunters. 37: 389-413

Möller, H. (1990). Association between diseases of flounder (Platichthys flesus) and environmental conditions in the Elbe estuary, FRG. J. Cons. int. Explor. Mer 46: 187-199 
Nounou, P., Martoja, R., Orcel, L. (1981). Ulcerations of marine fishes and mammals caught in the French coastal waters. Publ. French Nat. Centre Exploit. Oceans 43: 1-99

Oravainen, R. (1989), Vuosiyhteenveto, Kokemäenjoen ja Porin edustan merialueen yhteistarkkailusta vuodelta 1988 (Annual report of 1988 , inspection of the sea area outside the river of Kokemäenjoki and city of Pori). Kokemäenjoen vesistön vesiensuojeluyhdistys r.y. Julkaisu no. 219

Perkins, E. J., Gilchrist, J. R. S., Abbott, O. J. (1972). Incidence of epidermal lesions in fish of the north-east Irish Sea area, 1971. Nature 238: 101-103

Rodgers, L. J., Burke, J. B. (1981). Seasonal variation in the prevalence of 'red spot' disease in estuarine fish with particular reference to the sea mullet, Mugil cephalus L. J. Fish Dis. 4: 297-307

Shelton, R. G. J., Wilson, K. W. (1973). On the occurrence of lymphocystis, with notes on other pathological conditions, in the flatfish stocks of the north-east Irish Sea Aquaculture 2: 395-410

Suuronen, P. (1979). Kampelan (Platichthys flesus L.) yksilörunsaudesta, vaelluksesta, kasvusta ja kuolevuudesta Suomen lounaisrannikolla (The abundance, migration, growth and mortality of the flounder (Platichthys flesus L.) at the SW Finnish coast). Pro Gradu, University of Helsinki

Thulin, J., Höglund, J., Lindesjöö, E. (1989). Fisksjukdomar i kustvatten (Fish diseases in coastal waters of Sweden). Naturvårdsverket, Stockholm

Vethaak, A. D. (1985). Prevalence of fish diseases with reference to pollution of Dutch coastal waters. Netherlands Institute for Fishery Investigations, IJmuiden, RIVOReport CA 85-01 E: 1-70

Vethaak, A. D. (1987). Fish diseases, signals for a diseased environment? In: Peet, G. (ed.) Proceedings of the 2 nd North Sea seminar '86, Rotterdam, 1-3 Oct., Vol. 2, Reason for concern. Werkgroep Noordzee, Amsterdam, p. $41-61$

Vethaak, A. D. (1992). Diseases of flounder (Platichthys flesus L.) in the Dutch Wadden Sea, and their relation to stress factors. Neth. J. Sea Res. 29: 257-272

Wiklund, T. (1990). Atypical Aeromonas salmonicida isolated from ulcers of pike, Esox lucius L. J. Fish Dis. 13: 541-544

Wiklund, T., Bylund, G. (1985). Ulcer disease of flounder (Platichthys flesus L.) in the northern Baltic Sea. In: Eurnpean Association of Fish Pathologists, 2nd International Conference, 2-5 September 1985, Montpellier France. Programme and Abstracts. Eur. Ass. Fish Pathol., U.K., p. 100 (abstract)

Wiklund, T., Bylund, G. (1991). A cytochrome oxidase-negative bacterium (presumptively an atypical Aeromonas salmonicida) isolated from ulcerated flounders (Platichthys flesus L.) in the northern Baltic Sea. Bull. Eur. Ass. Fish Pathol. 11(2): 74-76

Manuscript first received: January 4, 1993

Revised version accepted: August 9, 1993
Responsible Subject Editor: T. Evelyn, Nanaimo, B.C., Canada 